\title{
THE WAYS TO INCREASE EFFICIENCY OF SOIL BIOREMEDIATION
}

\author{
SPOSOBY ZWIĘKSZENIA EFEKTYWNOŚCI BIOREMEDIACJI GLEB
}

\begin{abstract}
The aim of this paper was to present possibilities of using different substrates to assist the bioremediation of soils contaminated with heavy metals, pesticides and other substances. Today's bioengineering offers many solutions that enable the effective conduct of biological remediation, including both biostimulation and bioaugmentation. For this purpose, they are used to enrich various organic substances, sorbents, microbiological and enzymatic preparations, chemical substances of natural origin or nanoparticles. The use of genetic engineering as a tool to obtain microorganisms and plants capable of efficient degradation of pollutants may cause the risks that entails the introduction of transgenic plants and microorganisms into the environment. In order to determine the efficacy and possible effects of the various bioremediation techniques, it is required to conduct many studies and projects on a larger scale than only in the laboratory. Furthermore, it should be emphasized that bioremediation involves interdisciplinary issues and therefore, there is a need to combine knowledge from different disciplines, such as: microbiology, biochemistry, ecology, environmental engineering and process engineering.
\end{abstract}

Keywords: bioremediation, phytoremediation, soil, heavy metals, organic pollutants

\section{Introduction}

Nowadays concern for the environment is becoming increasingly important. Intensive industrialization, large-scale heavy metals and xenobiotics use, such as: oil, polycyclic aromatic hydrocarbons (PAH), BTEX (benzene, toluene, ethylbenzene and xylene), chlorinated hydrocarbons, eg polychlorinated biphenyls (PCB), trichlorethylene (TCE) and perchlorethylene, nitroaromatic compounds, organophosphorus compounds and solvents, pesticides $[1,2]$ can cause a number of environmental problems, including the possibility of harmful effects on the biogeochemical circulation of different elements and they can be toxic to organisms, including humans. Therefore, the risk associated with the accumulation of degradation-resistant contaminants in the environment is increasing and it is necessary to search for new, safe and often unconventional methods of dealing with pollution [3, 4].

Microorganisms play a "catalytic role" in the degradation and mineralization of various xenobiotics, their assimilation or transformation into non-toxic chemicals

\footnotetext{
${ }^{1}$ Division of Sanitary Biology and Biotechnology, Faculty of Civil and Environmental Engineering, Białystok University of Technology, ul. Wiejska 45E, 15-351 Białystok, Poland

* Corresponding author: e.wolejko@pb.edu.pl
} 
(biotransformation) [5]. The plants have the ability to detoxify certain xenobiotics (eg heavy metals, radionuclides) in the soil. The root system of plants and microorganisms living there also play a key role in phytoremediation and bioremediation. The interaction between plants and microorganisms in the rhizosphere zone is fundamental to phytotechnologies mechanisms [6].

Biological remediation using microorganisms and plants is generally regarded as a safe and inexpensive method of the removal harmful substances from the environment. Bioremediation offers an environmentally friendly, economically and socially acceptable removal of xenobiotics using microorganisms, plants and enzymatic remediation [4] and the yield of bioremediation processes will depend on the properties of the contaminants and environmental conditions [5, 7]. The main problem of bioremediation technologies is the removal of the most difficult degradable components from the environment and removing of residual pollutants in the final process of biodegradation. Continuous accumulation of highly toxic and hardly-degradable pollutants in the environment is a reason that why microorganisms are not fully effective in protecting the biosphere. Thus, in recent years, scientists suggest that bioremediation methods can be modified through the introduction of various preparations and substances (microbial, enzymatic, organic), which will increase the efficiency of biological remediation [7]. Moreover, to improve the efficiency of bioremediation, one is always searching the appropriate species of plants, more efficient in this process, and groups of microorganisms living in the rhizosphere zone that will support and influence the treatment of the soil environment [8]. Therefore, the main purpose of bioremediation is not to remove pollutants at all costs, despite the economic or technological reality, but to limit the risk of negative impact on the environment and thus on human health [7].

\section{Bioremediation techniques}

\section{Natural bioremediation}

Natural bioremediation is based on the natural biodegradation of pollutants using flora from the contaminated environment combined with monitoring the concentration of xenobiotics. This is the most commonly used method of removing contaminants from soil and groundwater. Natural bioremediation occurs automatically and is associated with the circuit of elements in the environment. Natural bioremediation is especially important in the case of spills of petroleum products, as their distribution is monitored, and the migration of contamination, growth rate, microbial activity and the presence of biogenic elements are tracked $[2,9]$.

The process of spontaneous purification of contaminated environment may be prolonged, which is associated with the spontaneous course of the physico-chemical reactions during the degradation of pollutants $[1,4]$ and with the specific enzymatic activity of the indigenous microorganisms living in this environment (eg enzyme inhibition by substrates or competition for degrading enzyme active sites, toxicity of biodegradation products of pollutants, competition for oxygen etc.). The ability of microorganisms to bioremediation of pollutants is based on their oxidation and decomposition (biodegradation), assimilation or transformation into non-toxic compounds such as $\mathrm{CO}_{2}$ and $\mathrm{H}_{2} \mathrm{O}$ (biotransformation) [4, 7].

The efficiency and rate of degradation of pollutants using naturally occurring microorganisms are influenced by many factors (Fig. 1). The first group of factors is 
composed of those associated with the properties of the substance causing contamination, and thus the molecular weight, chemical structure (simple compounds such as $n$-alkanes are more easily degraded than $e g$ hydrocarbons having aromatic carbon in their structure), solubility in water and organic solvents (hydrophilic and hydrophobic interactions). The second group contains abiotic factors, especially the concentration and the presence of toxic substances, as well as moisture content, oxygen concentration, temperature, $\mathrm{pH}$, redox potential, the presence of biogenic elements (mainly $\mathrm{N}, \mathrm{P}$ ) and mineral salts. The third group of factors comprises the presence therein of various microorganisms that can interact negatively or positively with each other, type and location of the secreted enzymes etc. $[9,10]$.

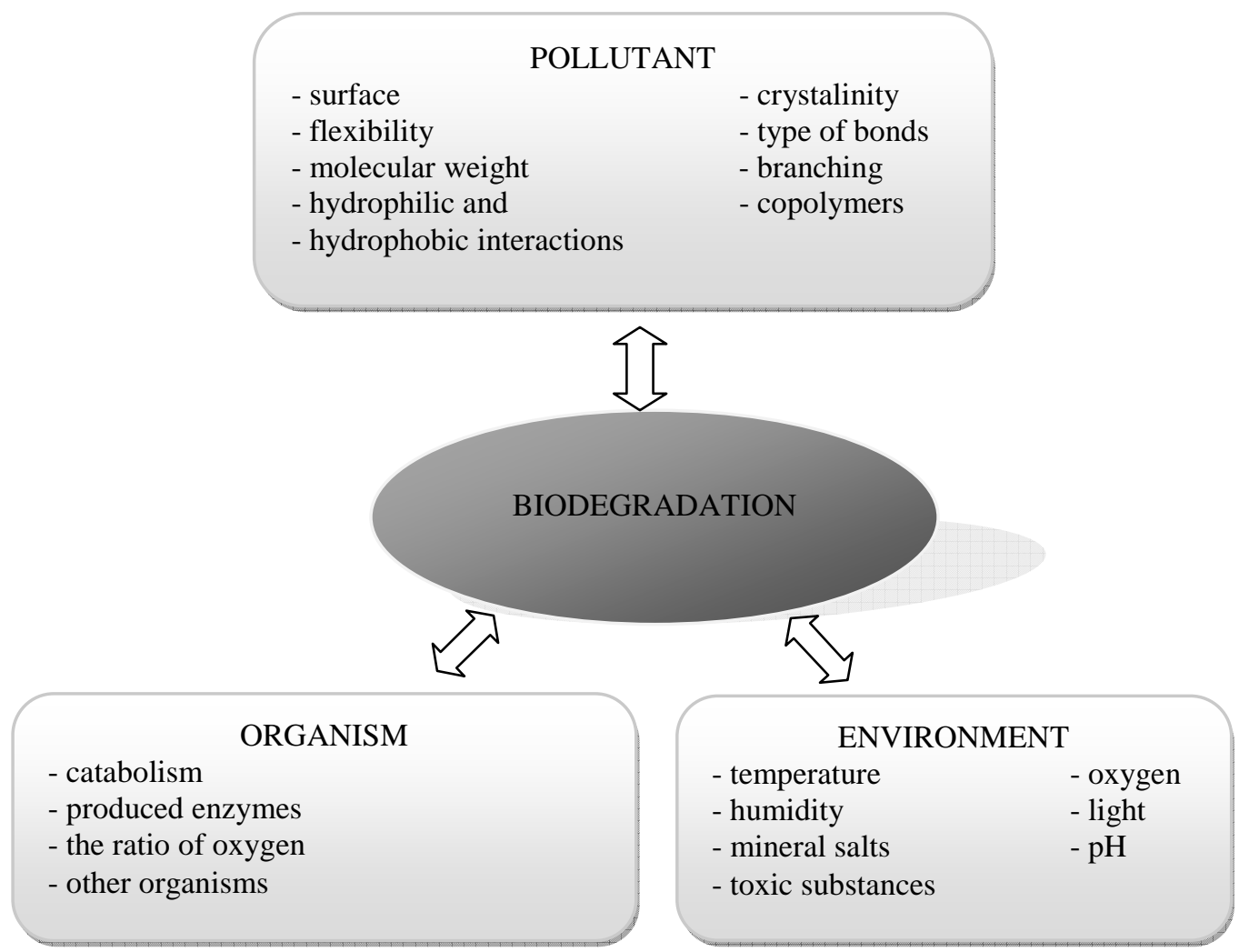

Fig. 1. Factors affecting the proper course of biodegradation of pollutants $[9,10]$

\section{Bioremediation engineering}

Bioremediation engineering is the sum of treatments including the removal of pollutants, primarily by microorganisms and plants. It can be carried out by in situ (contamination of site) and by ex situ (off-site contamination). Ex situ bioremediation requires an appropriate preparation of technological place. In the case of bioremediation of land, it may occur in special bioreactors, in piles (composting or biopiles) or landfarming $[2,6]$. 
Bioremediation engineering may include biostimulation, which involves the introduction of the media or other substrates to stimulate the indigenous microflora capable of degrading the contaminated environment, or bio-augmentation, consisting in adding the amplified microflora in the affected area. In addition, bioremediation may be assisted by supplying air or oxygen (bio-ventilation) $[6,11]$.

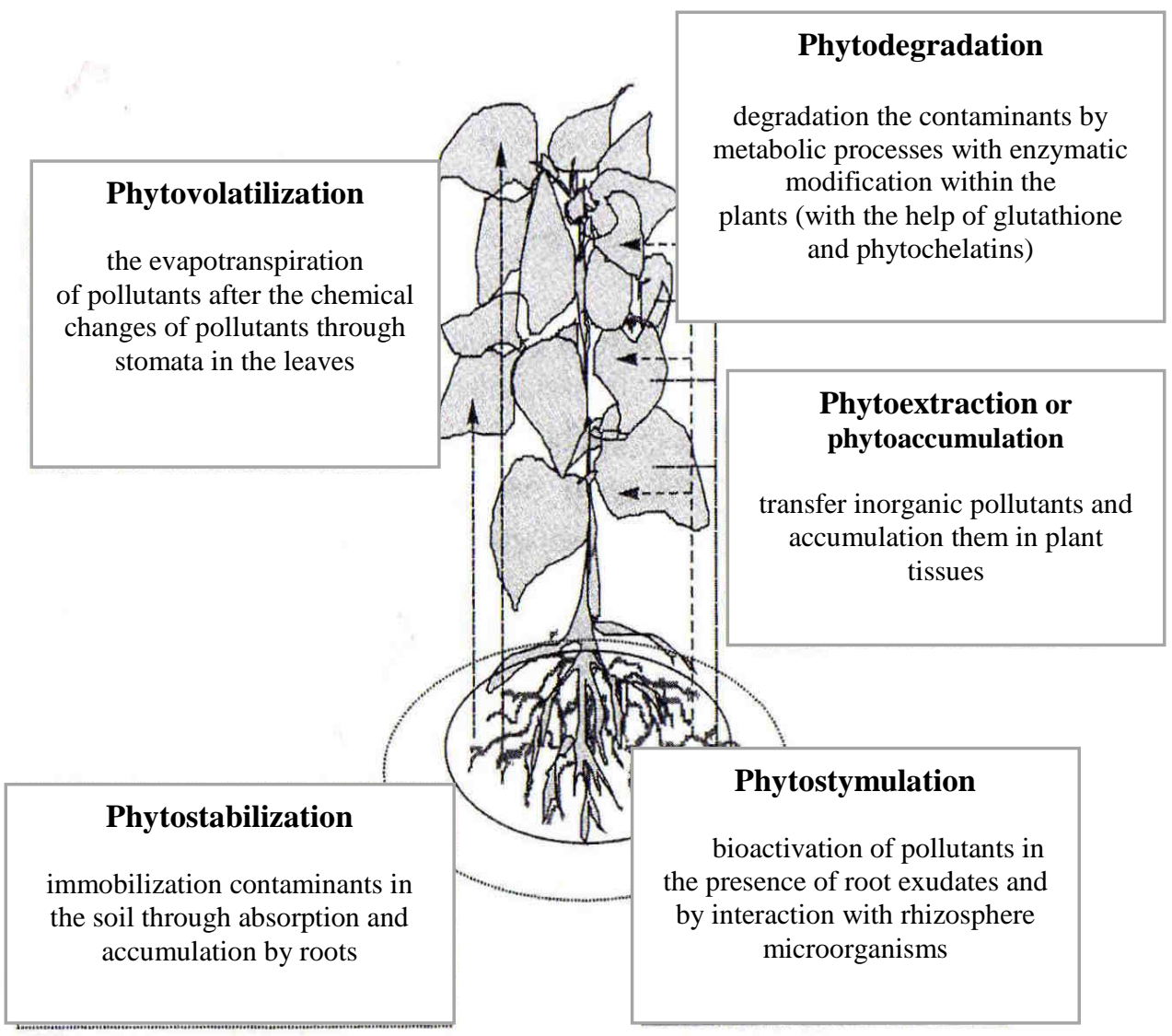

Fig. 2. The fate of contaminants during the phytoremediation $[6,11]$

In bioremediation one can also use the ability of plants to retrieve pollutants by aboverground and underground organs and to degrade xenobiotics in the rhizosphere zone, ie phytoremediation. Phytoremediation has many advantages, particularly low cost, public acceptance, the ability to simultaneously remove organic and inorganic compounds (mainly heavy metals and radionuclides, which cannot be converted chemically and can be toxic to microorganisms). The disposal of heavy metals by plants can occur in the following ways: phytovolatilization (bio-ventilation), phytoextraction (phytoaccumulation), phytostabilization and phytostymulation (Fig. 2) [4]. 


\section{Methods supporting bioremediation}

\section{Application of chemical compounds}

Different chemical compounds can be used to assist bioremediation. They are usually added to soil to stimulate the growth of microorganisms by supplementing nutrients (nitrogen and phosphorus), electron acceptors (oxygen), and substrates (methane) [12]. Nutrients are added to soil in order to increase the efficiency of decomposition of organic compounds eg PAHs and improve conditions for the growth of plants used in phytoremediation of soils contaminated with heavy metals [13, 14]. Aeration may be used to enhance the decomposition of saturated hydrocarbons of petroleum type pollutants (PCBs, PAHs) [15].

In order to increase the efficiency of the remediation, there are used different modifications, including the introduction of various chemical compounds into the environment. For example, one can add surfactants which adsorb pollutants on the surface and then release them by making them accessible to microorganisms [16]. Surfactants may be used to remove organic compounds (eg PAHs) and heavy metals from the soil. The substances containing surfactants are mainly used for washing of contaminated land. Among the compounds tested, the best results were obtained with washing solutions containing cyclodextrins and rhamnolipids (belonging to the group of glycolipids) [17].

The task of biostimulation is to modify the environment polluted by xenobiotics in a way ensuring the most effective immobilization and degradation of contaminants. It usually consists in delivery of nutrients, macro and microelements and oxygen, thereby increasing the activity of microorganisms of different strains [16, 13]. Kalantary et al [13] investigated the effect of delivery of macronutrients and micronutrients $(\mathrm{N}, \mathrm{P}, \mathrm{K}, \mathrm{Mg}, \mathrm{S}, \mathrm{Fe}$, $\mathrm{Cl}, \mathrm{Zn}, \mathrm{Mn}, \mathrm{Cu}, \mathrm{Na}, \mathrm{B}, \mathrm{Mo}, \mathrm{Co}$ and $\mathrm{Ni}$ ) to the contaminated soil [18]. A prepared medium contained various combinations of eleven mineral salts containing various macro- and microelements, which then were applied to soil contaminated with PAHs. The lowest concentration of phenanthrene was obtained at a high level of macronutrients in the range of $67-87 \%$ and a low level of microelements (12-32\%), where nitrogen was the dominant ingredient. The most effective biodegradation of phenanthrene proceeded in the following order $\mathrm{N}>\mathrm{K}>\mathrm{P}>\mathrm{Cl}>\mathrm{Na}>\mathrm{Mg}$ [19-21].

\section{Application of sorbents and organic substrates}

In the areas where there are refineries, gas stations and fuel pumping stations there is a risk of soil contamination by organic compounds from the fuel, which additionally contains dissolved toxic additives such as halogenated polycyclic hydrocarbons and other additives, which in soil tend to migrate primarily to groundwater and surface water, causing a threat. Fuel penetration into the permeable soil is held vertically, and after getting into the groundwater - horizontally. Therefore, it seems reasonable to apply in the first phase of soil remediation sorbents additionally enriched with active microbial biomass, as reported by Chen et al [5]. The task of the sorbent is primarily to inhibit migration of toxic and not readily degradable substances. Sorbent enrichment with microorganisms enhances bioremediation and additionally through the capture of nutrients can be a source of nutrients for microorganisms, thereby increasing the efficiency of the process. In the process of bioremediation supporting, one can use natural sorbents, eg from Sphagnum moss, which can be easily decomposed [18]. This solution presented in the work by Chen et al [5], where after the thermal treatment process, moss cells change their character from 
hydrophilic to hydrophobic, allowing for the absorption of hydrocarbons. Humic acids contained in the moss react with hydrocarbons, and the bacteria for which the hydrocarbons are the medium start to decompose them. The final product of biodegradation process was humus.

In bioremediation technologies, one can use powder materials with biosorbent properties on the lignin-cellulose basis (eg algae, fungi, among others Trichoderma harzianum) which has the ability to adsorpt hexavalent chromium which is soluble in water and toxic, and transforming it into the trivalent form, which is insoluble [22].

Sejakova et al [23] used for augmentation natural organo-mineral absorbents such as lignite, zeolites, and humic acids to degrade pentachlorophenol (PCP) in the soil. The authors have obtained the best results for of PCP degradation after using lignite. The presence of sorbents, mainly coal, enhanced the development of microorganisms present in the soil and their ability to bioremediation.

On soils contaminated with diesel fuel, one used activated carbon granules, which accelerated bioremediation of forest soil heavily contaminated with volatile petroleum products such as diesel oil. The introduction of granular activated carbon also decreased bio- and phytotoxicity of oil pollution of the soil [24].

Wolejko et al [14] reported on the possibility of adding organic substrates in the form of sewage sludge with low heavy metal content into contaminated urban soil. On the one hand the application of sewage sludge into the soil allowed for supplementing the organic matter in the soil, on the other hand, it provided valuable nutrients necessary for the growth of soil microorganisms and the proper development and growth of plants, which performs a cleansing function in the city. The studies by Wolejko et al [25] concerned the application of sewage sludge from a municipal wastewater treatment to the urban soil in Bialystok (Poland). The studies have shown that in the objects fertilized with sludge, the plants extracted more of $\mathrm{Cd}$ and $\mathrm{Zn}$ from the soil as compared to the control [14]. According to Achiba et al [26], heavy metals often behave differently in various soils. It is difficult to assess the metal pollution levels by determining the metal concentration in soils because many factors affect the distribution of heavy metals in soils, including physico-chemical properties of soils, redox potential, ligand etc. [26, 27]. Other factors limiting the use of sewage sludge in land reclamation are the odor and the risk of groundwater contamination [28].

The introduction of sorbents to the contaminated environment is typically connected with the inoculation of microorganisms capable of degrading specific pollutants, which treat given xenobiotics as a carbon source, thereby remediation becomes more efficient and occurs much faster. Additionally, different nutrients can be introduced (generally nitrogen and phosphorus), which facilitate the growth of microorganisms [5]. In the application of sorbents in bioremediation, it is important that they should be safe to the environment $[5,18]$.

\section{Application of biopreparations and enzymes}

When the rate of natural decomposition of pollutants is not sufficient, one applies the stimulation of native microflora in order to accelerate the process. One of methods is bioaugmentation, ie placing in the soil specially prepared microorganisms strains, which are characterized by high resistance and the ability to adapt to the contaminated environment, and the ability to decompose contaminants present in the environment, into which they are introduced. In addition, the microorganisms used in bioaugmentation should be 
characterized by mobility, the ability to adhere, elasticity (resistance to changes in $\mathrm{pH}$, metal concentration), short survival in an environment, where the lack of xenobiotics causes them to decay, and provide strong competition for the indigenous microflora [2, 29]. One of the conditions of supplying soil with microorganisms in the contaminated soil is to ensure that biopreparations placed in the soil should be completely safe for humans and the environment and that they should be certified by the National Institute of Hygiene, which guarantees that the introduced strains are not pathogenic [9].

Gestel et al [30] reported that anaerobic microorganisms are able to degrade hydrocarbons, such as benzene, toluene, ethylbenzene, xylene (BTEX), as well as hexadecane and naphthalene. The strains of Dechloromonas ( $\beta$-proteobacteria) completely oxidize benzene under anaerobic conditions, using nitrate as an electron acceptor [31]. Moreover, in the studies by Zhao et al [32], Klebsiella pneumoniae strain SCZ-1, a facultative anaerobic microorganism isolated from domestic anaerobic sludge, was used to successfully degrade hexahydro-1,3,5-trinitrio-1,3,5 triazine (RDX) and its mono-nitroso derivative (MNX) under aerobic conditions. The strain SCZ-1 degraded RDX to $\mathrm{HCHO}, \mathrm{CH}_{3} \mathrm{OH}(12 \%), \mathrm{CO}_{2}(72 \%)$ and $\mathrm{N}_{2} \mathrm{O}(60 \%)$ through the intermediary formation of methylenedinitramine. Furthermore, Nagata et al [33] used Sphingomonas paucimobilis UT26 aerobic bacterium to decompose $\gamma-\mathrm{HCH}$. The $\gamma-\mathrm{HCH}$ was transformed to 2,5-dichlorohydroquinone via sequential reactions catalyzed by following enzymes: LinA, LinB, and LinC. In turn, 2,5-dichlorohydroquinone is metabolized by LinD, LinE, LinF, LinGH and LinJ to succinyl-CoA and acetyl-CoA, which are further channeled into and metabolized in the tricarboxylic acid cycle [34, 35].

Even though little is known about the polychlorinated biphenyls (PCB) biodegradation mechanisms in fungi, they seem to play an important role in the transformation of PCBs [35]. Rubilar et al [36] investigated the ability of white rot fungi (Anthracophyllum discolour and Phanerochaete chrysosporium) to degrade pentachlorophenol to give the best results for the tested consortia of fungi immobilized on wheat grains as lignincellulose material. The test fungi were characterized by rapid growth and high production of lignin degradating enzymes, such as manganese peroxidase and lignin peroxidase, and the effective degradation of contaminants [37].

In bioremediation technologies, there is also a possibility of application of the bacterial strains with the ability to produce surfactants. The biosurfactants produced by microorganisms are usually stable in the soil environment, they stimulate enzymatic processes thereby improving the bioavailability of contaminants (eg PAHs and heavy metals). The examples of microorganisms producing such substances are, for example, Bacillus megaterium and Pseudomonas aeruginosa UG2, which are capable of decomposing the mixture of hydrocarbons [17, 38].

Increasing the efficiency of phytoremediation can be achieved by the introduction of microorganisms which have the natural ability to degrade pollutants. In this context, the rhizosphere plant zone is important, since it is inhabited by microorganisms living in close association with plants, more precisely with their root zone. Endophytes, ie bacteria and fungi that live in the vicinity of plant tissues or in the intercellular spaces without causing any disease, can help phytoremediation of contaminated soils with eg toluene, phenol, trichloroethanol and other toxic substances. Furthermore, endophytes introduced into the soil enhance plant growth and improve their resistance to unfavorable factors such as drought or infections [9]. Enhancing phytoremediation of contaminated soils with 'for example' heavy metals, could also include the introduction of microorganisms inhabiting 
the rhizosphere zone known as Plant-Growth-Promoting Rhizobacteria/Bacteria (PGPR/PGPB). These include, inter alia, Arthrobacter, Alcaligenes, Agrobacterium, Azospirillum, Azotobacter, Bacillus, Pseudomonas (P. fluorescens), Rhizobium, Serratia [38]. For example, strains of $P$. putida and $P$. fluorescens are resistant to contamination with $\mathrm{Cd}$ and $\mathrm{Pb}$, and also support phytoextraction of these elements in plants [39]. Attention should be paid to the use of transgenic Arabidopsis thaliana, with the bacterial gene merH, which is not only more resistant to toxic mercury chloride, but also has the ability to secrete mercury into the atmosphere in the non-toxic form [40]. Moreover, the effect of this group of microorganisms may also consist in the production of various compounds by the bacteria collected by plants (eg vitamins such as biotin, pantothenic acid, niacin, pyridoxine, thiamine), increasing the bioavailability of nutrients contained in the medium or inhibiting the development of pathogens and reducing the collection of compounds that inhibit the growth of the plants (eg ethylene and hydrogen cyanide) [39, 40].

The use of biopreparations has many advantages, but it also has many drawbacks. Before their introduction biopreparations require recovery to achieve full revival of degradation activity $[6,40]$. Furthermore, it is not possible to check before buying whether microorganisms contained in the biopreparation are not antagonists to microorganisms naturally present in the treated soil. The introduction of allochtonic microorganisms can cause disturbance in the ecosystem to the extent that the restoration of the biological balance of the remediation can be difficult. It seems most appropriate to use preparations made on the basis of the indigenous microflora, but in this case they must be individually adapted to any contaminated soil. This requires the isolation of native microorganisms and their selection in the laboratory where one determines taxonomic affiliation and eliminates the pathogenic microorganisms. Only preparations having the National Institute of Public Health - National Institute of Hygiene (NIPH - NIH) certificate can be used. Consequently, producing preparation is expensive and time consuming [41].

The increase in the amount of toxic compounds and insufficient rate of microorganisms growth in the environment often causes that the microorganisms do not have the ability to develop so many metabolic pathways for the degradation of pollutants [36]. Therefore, it seems reasonable to use in bioremediation processes not only metabolic potential of microorganisms, but also their enzymes in the form of preparations. The preparations may contain enzyme complexes or a single biocatalysts able to modify the structure or to change the toxicity of pollutants to non-toxic form. This solution is attractive, because the enzymes have a simpler structure than whole organisms. Moreover, in bioremediation one can use enzymes secreted outside the cell, as well as intracellular ones. The most studied enzymes in bioremediation are bacterial mono- or dioxygenases, reductases, dehalogenases, cytochrome P450 monooxygenase, phosphotriesterases, and enzymes involved in lignin metabolism (such as laccases, lignin- and manganese peroxidases) from white-rot fungi [1, 3, 42]. According to Arora et al [43], oxygenases play a key role in the metabolism of organic compounds by increasing their reactivity or water solubility or bringing about cleavage of the aromatic ring. Oxygenases have a broad substrate range and are active against a wide range of compounds, including the chlorinated aliphatics. Generally, the introduction of $\mathrm{O}_{2}$ into the organic molecule by oxygenase results in cleavage of the aromatic rings. Furthermore, halogenated methanes, ethanes, and ethylenes can be degraded by means of dehalogenation reactions in association with multifunctional enzymes [42]. 
According to Juwarkar et al [16], it is important to analyze the role of peroxidase in the treatment of the soil contaminated with aromatic compounds. Peroxidases catalyze the degradation and transformation of polycyclic aromatic hydrocarbons (PAHs), polychlorinated biphenyls (PCBs), chlorinated hydrocarbons, 2,4,6-trinitrotoluene, phenolic compounds and dyes. These enzymes are capable of degrading various types of resistant aromatic compounds [16, 44]. Moreover, except peroxidase, monooxygenases are also involved in the degradation of hydrocarbons, such as substituted methanes, alkanes, cycloalkanes, alkenes, haloalkenes, ethers, as well as aromatic and heterocyclic hydrocarbons [45]. Under oxygen-rich conditions, monooxygenase catalyzes oxidative dehalogenation reactions. As presented by Sing et al [44], reductive dechlorinating also takes place in anaerobic conditions [45]. Oxidation of substrate can lead to dehalogenation as a result of the formation of labile products that undergo subsequent chemical decomposition [33, 45]. Recent works have shown that lipase is also closely related to the organic pollutants present in the soil. Lipase activity is responsible for the drastic reduction of total hydrocarbon in the contaminated soil. Research undertaken in this area is likely to contribute to the knowledge on the bioremediation of oil spills [34, 46].

In the recent years, there has been an increase in the interest in fungal enzymes, which are able to degrade lignin and enzymes from the class of hydrolases capable of lipolysis [3]. According to Rubilar et al [36], many fungal species are considered to be suitable for the removal of chlorinated phenolic compounds from the contaminated environments. The activity of fungi is mainly due to the action of extracellular oxidoreductases, like laccase, manganese peroxidase, and lignin peroxidase, which are released from fungal mycelium into their nearby environment. Being filamentous, fungi can reach the soil pollutants more effectively than bacteria [47]. As indicated by the Chandra and Chowdhary [48], among the biological agents, laccases represent an interesting group of ubiquitous, oxidoreductase enzymes that show promise of offering great potential for biotechnological and bioremediation applications. Laccases not only oxidize phenolic and methoxyphenolic acids, but also decarboxylate them and attack their methoxy groups (demethylation). These enzymes are involved in the depolymerization of lignin, which results in a variety of phenols. In addition, these compounds are utilized as nutrients for microorganisms or repolymerized to humic materials by laccase [49].

The use of enzymes in the biodegradation process brings many benefits [50]. Firstly, biotransformation involving enzymes does not cause accumulation of toxic by-products, and the enzymes are digested after the completion of the process by the microorganisms dwelling in contaminated environments. Secondly, increasing the bioavailability of contaminants is more easily achieved than in the case of using whole cells [1, 51].

Both enzymatic detoxification and using biopreparations require strict control of the biodegradation process. In addition, they still require the development of methods for the manufacturing of the enzyme preparations intended specifically for bioremediation technologies and optimizing the production of enzymes in terms of financing [3, 52]. Therefore, it seems that the most effective solution would be to use the bioremediation techniques combining the potential of microorganisms with the use of enzymes [3].

\section{Genetic modifications of microorganisms}

Genetic engineering aims to modify microorganisms and enzymes so that they would have the ability to degrade a variety of xenobiotics. Of course, the degree of degradation 
will depend on the catalytic efficiency of enzymes present in the cells or the ones induced to particular substrates [9].

The microorganisms active in the degradation of $n$-alkanes are characterized by the presence of such genes as: $\operatorname{alkB}$, alkB1, alkB2, alkM, aromatic hydrocarbons: $x y l E$, and polycyclic aromatic hydrocarbons: $n d o B$, nidA, in most cases located on plasmids, so that they can be subject to a horizontal transfer $[10,53]$. Then they can also be used as markers for the identification of microbial biodegradation [10]. For example, transgenic tobacco has a significantly increased ability to metabolize trichloroethylene in comparison with control. The use of transgenic plants for phytoremediation support can be very effective, but often it may not be possible, primarily due to the strict regulations and safety reasons, as in the case of the use of modified bacteria $[9,54]$.

When using microorganisms in the soil treatment, the use of genetic engineering to improve the ability of microorganisms to degrade contaminants opens many interesting opportunities of obtaining microorganisms which are able to degrade various pollutants in high effectiveness. Researchers have suggested that the modified microorganisms have a higher potential of environmental cleanup than the natural ones $[16,55,56]$.

Particular attention is paid to the genetic engineering of bacteria using a bacterial hemoglobin (VHB) to purify the environment from aromatic organic compounds under conditions of hypoxia. Moreover, new recombinant DNA techniques are used to obtain microorganisms capable of pollutants biodegradation including synthetic small molecules $[38,54]$. These techniques include, among others, new vectors to introduce heterologous genes into a host organism or new mechanisms controlling gene expression, the use of targeted and random mutagenesis in order to increase the activity of biodegrading enzymes. Fluorescence in situ hybridization (FISH), PCR in situ, and quantitative PCR can be powerful tools for detection of target microorganisms directly related to the degradation of pollutants [16].

However, in the case of genetic modification of microorganisms, their introduction into the contaminated sites in order to enhance bioremediation may have adverse effects on the environment, such as the transfer of genes $[16,56]$.

\section{Genetic modifications of plants}

Genetic engineering of plants, by insertion or overexpression of specific genes in the plant genome, provides an effective method of increasing plants capacity of phytoremediation. Most of the tested genes are involved in the metabolism, absorption, or transport of certain pollutants. In order to "create" an ideal plant purifying the environment, the influence of overexpression of genes encoding different enzymes, important for this process, was studied in many plant species. In particular using plants expressing high levels of cytochrome P450s is considered to be a potential strategy for phytoremediation of xenobiotics [9].

Microorganisms and plants presented in the work by Mello-Farias and Chaves [58] have potential for metal adsorption, accumulation or resistance, which depends on the synthesis of metal binding proteins such as metallothioneins (MTs) or phytochelatins (PCs). They are major sulfur-containing classes of metal chelating ligands identified in plants and they play a significant role in plant metal tolerance $[59,60]$. According to Sriprang and Murooka [59], metal binding to proteins is site specific and it has been reported that hard metals preferentially bind to Asp and Glu rich proteins [61], while soft metals tend to bind to Cys and His rich proteins [62]. Moreover, metal detoxification and hyperaccumulation 
within the plant occur mainly through chelation by high affinity ligands. Extracellular and/or intracellular complexation with ligands is a process associated to heavy metal pollutants [58, 63, 64]. According to Hossain et al [65], the PCs are synthesized from L- $\gamma$-glutamyl-L-cysteinylglycine (GSH), the metal binds to the constitutively expressed enzyme - $\gamma$ glutamylcysteinyl dipeptidyl transpeptidase (PC synthase), thereby, activating it to catalyze the conversion of GSH to phytochelatin $[65,66]$. Furthermore, as presented in the work by Xiang and Oliver [67], a number of mechanisms are likely to be involved in the regulation of $\mathrm{PC}$ biosynthesis eg in Arabidopsis plants $\mathrm{Cd}$ and $\mathrm{Cu}$ stimulate the transcription of genes encoding GSH reductase, $\gamma$-glutamylcysteine synthetase (GCS) and glutathione synthetase (GS) which are involved in the glutathione biosynthetic pathway [67]. MTs typically contain two metal-binding, cysteine-rich domains, which gives them a dumbbell conformation. MT proteins are classified based on the arrangement of the Cys residues [68] and they can be classified into four sub-families [69]. The biosynthesis of MTs presented in the work by Yang et al [64] is regulated at the transcriptional level and it is induced by several factors, such as hormones, cytotoxic agents and metals including $\mathrm{Cd}$, $\mathrm{Zn}, \mathrm{Hg}, \mathrm{Cu}, \mathrm{Au}, \mathrm{Ag}, \mathrm{Co}, \mathrm{Ni}$ and $\mathrm{Bi}$. The studies performed to quantify the mRNA level in different tissues allowed for concluding that MT genes are differentially regulated in a tissue-specific manner and in relation to the developmental stage, and are stimulated by environmental factors such as heavy metals [70, 71].

Heaton et al [72] in their study observed greater resistance to contamination with toxic organic mercury after the bacterial merAB operon transfer to the chloroplast genome of tobacco plant [73].

\section{Application of nanoparticles}

In future-assisted bioremediation, one may use nanoparticles, ie particles of a size of 1-100 $\mathrm{nm}$, naturally occurring ( $\mathrm{eg}$ volcanic ash, natural composites) as well as man-made (eg nZVI, $\mathrm{Fe}_{3} \mathrm{O}_{4}$-PAA, $\mathrm{Fe}_{2} \mathrm{O}_{3}, \mathrm{SnO}_{2}, \mathrm{Al}_{2} \mathrm{O}_{3}, \mathrm{SiC}, \mathrm{BaZrO}_{3}$ ). The advent of nanotechnology brings potential benefits to the environment; nanoparticles are gentle to the environment and/or are sustainable (environmentally sustainable) products (such as green chemistry preventing pollution); another is the remediation of contaminated materials and chemicals used as sensors of changes in the environment [74]. The potential of nanoparticles can be used in breaking down organic compounds, such as polychlorinated biphenyls (PCB) and chlorinated hydrocarbons (PCH). As presented by Fan et al [75], to enhance PCB removal from soils, low-level direct current and Fe/Pd bimetallic nanoparticles in conjunction with surfactants (eg saponin and Tween 80 ) were used and after 14 days a $20 \%$ PCB removal from soils was obtained. Another example of the use of nanoparticles in bioremediation is the use of carbon nanotubes capable of stronger adsorption of dioxins in comparison with a conventionally activated carbon. Furthermore, in the case of the rehabilitation of soils polluted with heavy metals nanoparticles of hydroxyapatite are used. Studies have shown that the hydroxyapatite particles have decreased bioavailability of $\mathrm{Cu}$ and $\mathrm{Zn}$ in the soil. Iron nanoparticles have the potential of reclamation and disposal of not readily degradable substances [16].

The various mechanisms employed for the synthesis of nanoparticles by the microorganisms include alteration of solubility and toxicity through reduction or oxidation, lack of specific metal transport system, biosorption, extracellular complexation or precipitation of metals, bioaccumulation and efflux system [75, 76]. Shin and Cha [77] demonstrate that so far, very limited studies have been reported on nanoparticle effect on 
the microbiological reaction rates. Moreover, the higher activity of nanoparticles is usually referred to as their unique properties and high available active specific surface areas. Generally, nanoparticle catalysts increase the microbiological reaction rates by locating them in the cells to stimulate the activity of microbes [78]. As indicated by Hulkoti and Taranath [79], fungi are also considered an excellent candidates for the synthesis of metal and metal sulfide nanoparticles due to the presence of a variety of enzymes in their cells and the simple handling. Fungi, when compared with bacteria, synthesize a large amount of nanoparticles. Fungi, secrete more amount of proteins, which results in the higher productivity of nanoparticle [76].

Recent works have shown that green synthesis of gold nanoparticles using organelles may be an exciting alternative to methods currently available. When research had been conducted on bioreduced $\mathrm{Au}^{3+}$ to $\mathrm{Au}^{0}$ nanoparticles in plants by Sharma et al [80], they discovered that many gold nanoparticles surrounded organelles. Moreover, Beattie and Haverkamp [81] demonstrated that chloroplasts were the site of the most abundant reduction of $\mathrm{Au}^{3+}$ salts to $\mathrm{Au}^{0}$ nanoparticles in plants. This prompted the authors to investigate the possibility of biosynthesized gold nanoparticles using chloroplasts as biological templates and the chloroplasts acted in dual roles, ie as reducing agents and stabilizers in the course of the formation of gold nanoparticles [82].

Liu and Zhao [83] prepared and tested the properties of a new class of iron phosphate (vivianite) nanoparticles for in situ immobilization of $\mathrm{Pb}^{+2}$ in soils. The authors concluded that phosphate nanoparticles could effectively reduce bioavailability and mobility of $\mathrm{Pb}^{2+}$ from soil.

Although nanoparticles are used in various areas of life, there is concern that nanoparticles used for remediation after some time can release dangerous compounds, having a negative impact on people and the environment. For example, nanotubes and nanofibers can damage cell walls and thereby weaken the cell. Some molecules can also be bactericidal. Potentially toxic effects of nanoparticles on the environment and the organisms are not yet known, and probably there will be revealed in the coming years. There is a need to conduct much more research to understand the fate and transport of nanoparticles in the environment, meet their sustainability and toxicological effects on various biological systems, including humans $[82,84]$.

\section{Methods of effectiveness evaluation of the bioremediation process}

Genetic technology plays an important role in the process of bioremediation. It allows for analyzing, monitoring and assessing of the implementation. Nowadays, constantly improved modern methods ensuring high efficiency are used, such as: fingerprinting real-time polymerase chain reaction (PCR), genotypic profiling, ultrafast genome pyrosequencing, metagenomics, metatranscriptomics, metaproteomics and metabolomics $[8,16,85,86]$.

Microbial community analysis is possible by using terminal restriction fragment length polymorphism (T-RFLP). It is based on the location of restriction enzyme site present nearest to the labeled end of amplified targeted gene. Stable isotope probing (SIP) is based on labeling of DNA/RNA/fatty acids by stable isotopes. This technique allows for obtaining information about microbial diversity in an environmental niche. Fatty acid methyl ester (FAME) analysis is the extraction of specific methyl ester profiles of microorganisms. Methyl ester derivatives from the extracted lipids are used to evaluate microbial community 
structure, but they may be used only in pure cultures of bacteria. Monitoring of community structure is possible by using biosensors which are specific bioactive compound emitting signals $[87,88]$.

The microorganisms are very sensitive, they react quickly to any kind of changes (natural and anthropogenic) in the environment, and quickly adapt themselves to new conditions $[8,89]$. Despite the small demand for some elements, including heavy metals, microorganisms take them into the cell in significant amounts. This phenomenon leads to the intracellular accumulation of metal cations of the environment and is defined as bioaccumulation [90, 85]. Adapting to new conditions can be observed by monitoring changes in the quantity and quality of population and microbial activity $[8,91]$. The biomass of bacteria accumulating heavy metals can be determined by atomic absorption spectrometry technique (Atomic Absorption Spectrometry - AAS). It is one of the most widely used methods of trace analysis of instrumental analytical chemistry [92].

The changes occurring in microbial population are the sum of physical, chemical and biological factors influencing the soil ecosystems [8, 92]. Desai et al [8] and Gupta et al [93] report that to determine the structure, dynamics and function of the microbial population, two kinds of methods are currently used: conventional methods (abundance, biomass, enzymatic activity) and modern molecular methods: analysis 16S rDNA PCR-DGGE, TGGE PCR-T-RFLP analysis of fatty acids - fames, PLFAs, analysis of mRNA BIOLOGTM system, in situ hybridization - FISH, SIP - stable isotope probing and "-omics" methods (Fig. 3) [86, 94].

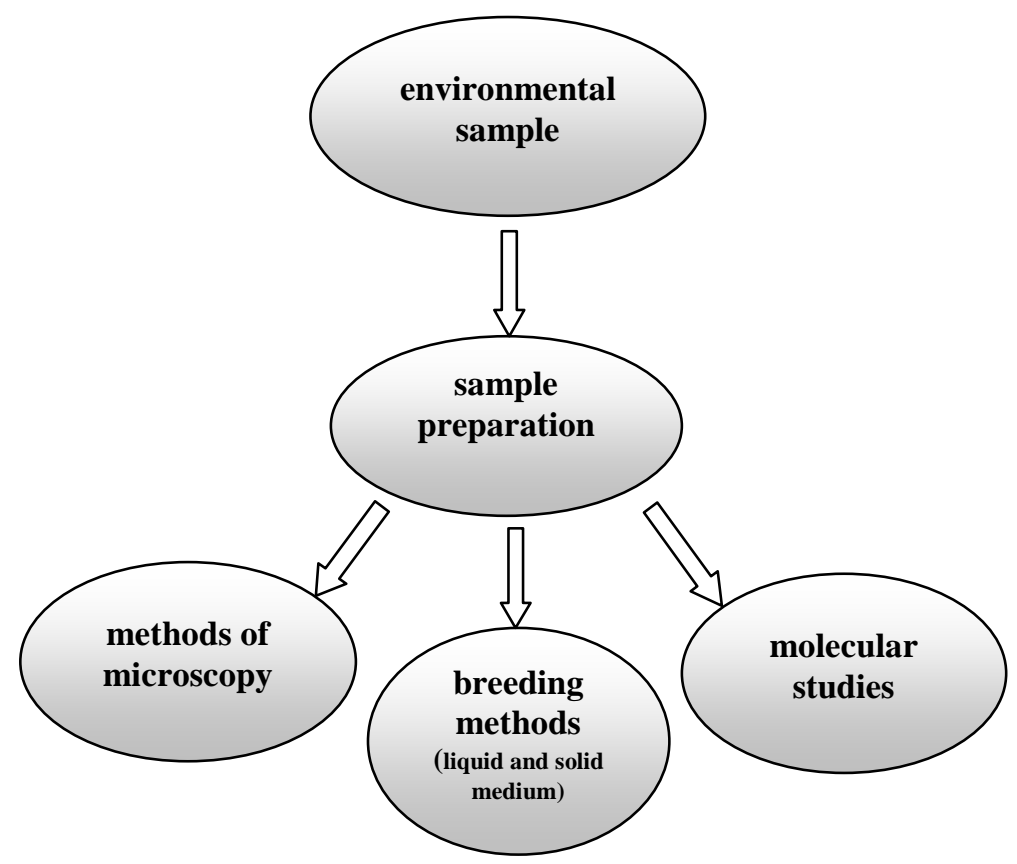

Fig. 3. Microbiological methods used to assess the quality of contaminated soils [94] 
Monitoring changes in the bacterial diversity in the environment and providing new information on the bioremediation process optimization, validation and impact on the ecosystem may be possible due to microbial molecular fingerprinting techniques as the $16 \mathrm{~S}$ ribosomal DNA (rDNA) of the bacterial cell (ie denaturing gradient gel electrophoresis (DGGE), and terminal restriction fragment length polymorphism (T-RFLP) [16]. In addition to these fingerprinting techniques, two tagging methods for high-throughput profiling of complex microbial communities have been developed recently: a serial analysis of ribosomal sequence tags/ribosomal DNA (SARST or SARD) [54] and single-point genome signature tags (SP-GSTs) [57]. According to Neufeld et al [74], these techniques provide a fingerprint of microbial communities in the form of concatemers of PCR-amplified tag sequences. In the SARST/SARD method, PCR amplification targets short information-rich sequences of hypervariable regions of bacterial 16S rRNA genes. Then, the amplicons are ligated to yield concatemers with multiple, serially arranged PCR products that are further cloned and sequenced to characterize microbial community composition. In this way, multiple ribosomal sequence tags (RSTs) from many different organisms are obtained simultaneously from a single sequencing reaction [54, 74].

In some European countries, programs were developed for the monitoring of soil (European Soil Monitoring Programmes), in which in addition to physical and chemical parameters, various biological indicators were introduced for soil assessment. According to Nielsen and Winding [95], in Germany the monitoring system comprises the following biological parameters: respiration, biomass, enzyme activity, and in the Netherlands - the biomass activity, activity of $\mathrm{C}$-mineralization and $\mathrm{N}$-mineralization processes, DGGE, BIOLOGTM, The United Kingdom - biomass, respiration, enzymatic activity (cellulase, catalase), BIOLOGTM, analysis of fatty acids (PLFA), Austria - biomass, enzymatic activity (dehydrogenase, arylosulphatase, proteases), nitrification [95, 96].

Ecotoxicological tests are other important parameters of assessing the effectiveness of the processes. They use living organisms as an indicator and their reaction is the basis for the evaluation of the tested system. The living organisms used in biotests must conform to strict requirements, including continuous availability and genetic homogenity. Ready-made tests in a form of a package are currently implemented, which allow for the evaluation of the toxicity of samples in a short time. They contain cryptobiotic forms of bioindicators from the standard culture. They can be stored for a long time and, if necessary, in a short time prepared for the test allowing for determining their total toxicity of all hazardous substances, and in many cases acting synergistically [97]. In the case of bioindication, the essence is to assess the general toxicity of the tested system, no matter which compound is toxic. The total effect of their activities is important [35].

The organisms used in the tests are selected for their special sensitivity to chemicals, which are harmful to humans. In the studies, kits of biotests tend to be used, in which the tested organisms belong to different trophic levels (producers, consumers and destruents). Among the ecotoxicological tests, Microtox (Aliivibrio fischeri using bacteria) has proved to be a useful tool in the evaluation of the toxicity of soils contaminated with petroleum hydrocarbons and heavy metals [94, 98]. Other tests used for toxicological assessment of soil are: a direct contact test of assessment of acute and chronic toxicity using shellfish Heterocypris incongruens (Ostracodtoxkit ${ }^{\mathrm{TM}}$ ), a test of germination and early plant growth (Phytotoxkit TM). In a standard test, there are three main types of plants selected due to the speed of germination and root growth rate: monocots - sorghum (Sorghum saccharatum), dicotyledonous - cress (Lepidium sativum) and mustard (Sinapis alba) [58, 99]. 


\section{Conclusion}

In the recent years, there has been a growing interest in bioremediation methods because they are effective, cheap and environmentally friendly ways to protect the environment. Often, self-cleaning environment process is not sufficient and it is necessary to apply additional treatments and different substrates and preparations supporting the biological treatment process.

Today's bioengineering offers many solutions that enable the effective conduct of biological remediation, including both biostimulation and bioaugmentation. For this purpose, one uses various organic substances, sorbents, microbiological and enzymatic preparations, chemical substances of natural origin or nanoparticles. It is important that the used substrates or products do not adversely affect the environment and easily undergo biodegradation. The unpredictability on far-reaching consequences of their use for humans and the environment is a significant drawback. Therefore, one needs many years of research to know the fate, transport, and durability. Using sorbents or nanoparticles in the environment and toxicological effects in different ecosystems, including the human being [100].

Bioremediation in situ is most popular and effective but it has drawbacks such as seasonal variation in the microbial activity and problematic application of treatment additives in the natural environment. Moreover, in the case of modified microorganisms may become uncontrollable. In this case, bioremediation is often limited only to analyses in specialized laboratories in experimental closed systems, eg in a special microcosms, mesocosms, bioreactors, hydroponics and green houses. Such research is not conducted in the natural conditions in soil [12].

In order to determine the efficacy and possible effects of the various bioremediation techniques, it is required to conduct many studies and projects on a larger scale than only in the laboratory. Furthermore, it should be emphasized that bioremediation involves interdisciplinary issues and therefore, there is a need to combine knowledge from different disciplines, such as: microbiology, biochemistry, ecology, environmental engineering and process engineering.

\section{Acknowledgements}

This work was done with financial support of S/WBiIS/3/2015.

\section{References}

[1] Alcade M, Ferrer M, Plou FJ, Ballesteros A. Environmental biocatalysis: from remediation with enzymes to novel green processes. Trend Biotechnol. 2006;24:281-287. DOI: 10.1016/j.tibtech.2006.04.002.

[2] Ayotamuno JM, Kogbara RB, Agoro OS. Biostimulation supplemented with phytoremediation in the reclamation of a petroleum contaminated soil. World J Microb Biot. 2009;25:1567-1572. DOI: 10.1007/s11274-009-0045-z.

[3] Nath A, Chakraborty S, Bhattacharjee C. 20 - bioreactor and enzymatic reactions in bioremediation. In: Das S, editor. Microbial Biodegradation and Bioremediation. Elsevier Inc. 2014, 455-495. DOI: 10.1016/B978-0-12-800021-2.00020-0

[4] Rayu S, Karpozaus DG, Singh BK. Emerging technologies in bioremediation: constraints and opportunities. Biodegradation. 2012;23:917-926. DOI: 10.1007/s10532-012-9576-3.

[5] Chen M, Xu P, Zeng G, Yang C, Huang D, Zhang J. Bioremediation of soils contaminated with polycyclic aromatic hydrocarbons, petroleum, pesticides, chlorophenols and heavy metals by composting: Applications, microbes and future research needs. Biotech Adv. 2015;33:745-755. DOI: 10.1016/j.biotechadv.2015.05.003. 
[6] Singh A, Kuhad RC, Ward OP. Biological remediation of soil: an overview of global market and available technologies. In: Singh A, Kuhad RC, Ward OP. editors. Advances in Applied Bioremediation. Berlin. Heidelberg: Springer; 2009;17:1-20. DOI: 10.1007/978-3-540-89621-0_1.

[7] Das N, Chandran P. Microbial degradation of petroleum hydrocarbon contaminants: An overview. Biotech Res Inter. 2011;1-13. ID 941810. DOI: 10.4061/2011/941810.

[8] Desai C, Pathak H, Madamwar D. Advances in molecular and "-omics" technologies to gauge microbial communities and bio remediation at xenobiotic/anthropogen contaminated sites. Biores Technol. 2009;101(6):1558-156. DOI: 10.1016/j.biortech.2009.10.080.

[9] Kang JW. Removing environmental organic pollutants with bioremediation and phytoremediation. Biotechnol Lett. 2014;36:1129-1139. DOI: 10.1021/es203753b.

[10] Simarro R, González N, Bautista LF, Molina MC. Assessment of the efficiency of in situ bioremediation techniques in a creosote polluted soil: Change in bacterial community. J. Hazard Mater. 2013;262:158-167. DOI: 10.1016/j.jhazmat.2013.08.025

[11] Hammond-Kosack KE. Biotechnology: Plant Protection. In: Smithers G, editor. Reference Module in Food Science. Elsevier Inc. 2014. DOI: 10.1016/B978-0-444-52512-3.00248-5

[12] Mani D. Kumar C. Biotechnological advances in bioremediation of heavy metals contaminated ecosystems: an overview with special reference to phytoremediation. Int J Environ Sci Technol. 2014;11:843-872. DOI: 10.1007/s13762-013-0299-8.

[13] Kalantary RR, Mohseni-Bandpi A, Esrafili A, Nasseri S, Ashmagh FR, Jorfi S, et al. Effectiveness of biostimulation through nutrient content on the bioremediation of phenanthrene contaminated soil. J Environ Health Sci Eng. 2014;12(1):143. DOI: 10.1186/s40201-014-0143-1.

[14] Wołejko E, Butarewicz A, Wydro U, Łoboda T. Advantages and potential risks of municipal sewage sludge application to urban soil. Desalin Water Treat. 2014;52:3732-3742. DOI: 10.1080/19443994.2014.884714.

[15] Jovančićević B, Antić M, Pavlović I, Vrvić M, Beškoski V, Kronimus A, et al. Transformation of petroleum saturated hydrocarbons during soil bioremediation experiments. Water Air Soil Pollut. 2008;190:299-307. DOI: $10.1007 / \mathrm{s} 11270-007-9601-\mathrm{z}$.

[16] Juwarkar AA, Singh SK, Mudhoo A. A comprehensive overview of elements in bioremediation. Rev Environ Sci Biotechnol. 2010;9:215-288. DOI: 10.1007/s11157-010-9215-6.

[17] Olkowska E, Ruman M, Kowalska A, Polkowska Ż. Determination of surfactants in environmental samples. Part I. Cationic compounds. Ecol Chem Eng S. 2013;20(1):69-77. DOI: 10.2478/eces-2013-0005.

[18] Gautam RK, Mudhoo A, Lofrano G, Chattopadhyaya MC. Biomass-derived biosorbents for metal ions sequestration: Adsorbent modification and activation methods and adsorbent regeneration. J Environ Chem Eng. 2014;2(1): 239-259. DOI: 10.1016/j.jece.2013.12.019.

[19] Lors C, Damidot D, Ponge JF, Périé F. Comparison of a bioremediation process of PAHs in a PAH-contaminated soil at field and laboratory scales. Environ Pollut. 2012;165:11-17. DOI: 10.1016/j.envpol.2012.02.004.

[20] Piekutin J, Skoczko I, Wysocki R. Zastosowanie koagulacji do usuwania związków ropopochodnych po napowietrzaniu. (Application of coagulation process for removal of petroleum hydrocarbons after aeration). Roczn Ochr Środ. 2015;17:1715-1726.

[21] Piekutin J, Skoczko I. Use of stripping tower and reverse osmosis in removal of petroleum hydrocarbons from water. Desalin Water Treat. 2014;52(19-21):3714-3718. DOI: 10.1080/19443994.2014.887497.

[22] Mukherjee K, Saha R, Ghosh A, Ghosh SK, Maji PK, Saha B. Surfactant-assisted bioremediation of hexavalent chromium by use of an aqueus extract of sugarcane bagasse. Res Chem Intermed. 2014;40:1727-1734. DOI: 10.1007/s11164-013-1077-4.

[23] Sejakova Z, Dercova K, Tothova L. Biodegradation and ecotoxicity of soil contaminated by pentachlorophenol applying bioaugmentation and addition of sorbents. World $\mathrm{J}$ Microbiol Biotechnol. 2009;25:243-252. DOI: 10.1007/s11274-008-9885-1.

[24] Semenyuk NN, Yatsenko VS, Strijakova ER, Filonov AE, Petrikov KV, Zavgorodnyaya YA, et al. Effect of activated charcoal on bioremediation of diesel fuel contaminated soil. Microbiology. 2014;83(5):589-598. DOI: 10.1134/S0026261714050221.

[25] Wołejko E, Wydro U, Butarewicz A, Łoboda T. Effects of sewage sludge on the accumulation of heavy metals in soil and in mixtures of lawn grasses. Environ Prot Eng. 2013;39(2):67-76. DOI: 10.5277/EPE130207.

[26] Achiba WB, Gabteni N, Lakhdar A, Laing GD, Verloo M, Jedidi N, et al. Effects of 5-year application of municipal solid waste compost on the distribution and mobility of heavy metals in a Tunisian calcareous soil. Agric Ecosyst Environ. 2009;130(3-4):156-163. DOI: 10.1016/j.agee.2009.01.001.

[27] Kabala C, Singh BR. Fractionation and mobility of copper, lead, and zinc in soil profiles in the vicinity of a copper smelter. J Environ Qual. 2001;30:485-492. DOI: 10.2134/jeq2001.302485x. 
[28] Singh RP, Agrawal M. Potential benefits and risks of land application of sewage sludge. Waste Manage. 2008;28:347-358. DOI: 10.1016/j.wasman.2006.12.010.

[29] Khan S, Afzal M, Iqbal S, Khan QM. Plant-bacteria partnerships for the remediation of hydrocarbon contaminated soils. Chemosphere 2013;90(4):1317-1332. DOI: 10.1016/j.chemosphere.2012.09.045.

[30] Gestel KV, Mergaert J, Swings J, Coosemans J, Ryckeboer J. Bioremediation of diesel oil-contaminated soil by composting with biowaste. Environ Pollut. 2003;125:361-68. DOI: 10.1016/S0269-7491(03)00109-X.

[31] Coates JD, Chakraborty R, Mcinerney MJ. Anaerobic benzene biodegradation - a new era. Res Microbiol. 2002;153:621-628. DOI: 10.1016/S0923-2508(02)01378-5.

[32] Zhao JS, Halasz A, Paquet L, Beaulieu C, Hawari J. Biodegradation ofhexahydro1, 3,5-trinitro-1,3,5-triazine and its mononitroso derivative hexahydro-1-nitroso-3,5-dinitro-1,3,5-triazine by Klebsiella pneumoniae strain SCZ-1 isolated from an anaerobic sludge. Appl Environ Microbiol. 2002;68:5336-5341. http://aem.asm.org/content/68/11/5336.full.

[33] Nagata Y, Endo R, Ito M, Ohtsubo Y, Tsuda M. Aerobic degradation of lindane ( $\gamma$-hexachlorocyclohexane) in bacteria and its biochemical and molecular basis. Appl Microbiol Biotechnol. 2007;76(4):741-752. DOI: 10.1007/s00253-007-1066-x.

[34] Mencía M, Martínez-Ferri AI, Alcalde M, De Lorenzo V. Identification of a $\gamma$-hexachlorocyclohexane dehydrochlorinase (LinA) variant with improved expression and solubility properties. Biocatal Biotransfor. 2006;24(3):223-230. DOI: 10.1080/10242420600667809.

[35] Passatore L, Rossetti S, Juwarkar AA, Massacci A. Phytoremediation and bioremediation of polychlorinated biphenyls (PCBs): State of knowledge and research perspectives. J Hazard Mater. 2014;278:189-202. DOI: 10.1016/j.jhazmat.2014.05.051.

[36] Rubilar O, Tortilla G, Cea M, Acevedo F, Bustamante M, Gianfreda L, et al. Bioremediation of a Chilean Andisol contaminated with pentachlotophenol (PCP) by solid substrate cultures of white-rot fungi. Biodegradation. 2011;22:31-41. DOI: 10.1007/s10532-010-9373-9.

[37] Sessitsch A, Kuffner M, Kidd P, Vangronsveld J, Wenzel WW, Fallmann K, et al. The role of plant-associated bacteria in the mobilization and phytoextraction of trace elements in contaminated soils. Soil Biol Biochem. 2013;60:182-194. DOI: 10.1016/j.soilbio.2013.01.012.

[38] Zaidi A, Wani PA, Khan MS. Bioremediation: A natural method for the management of polluted environment. In: Toxicity of Heavy Metals to Legumes and Bioremediation. Zaidi A, Wani PA, Khan MS, editors. Berlin Heidelberg: Springer; 2012;101-114.

[39] Susarlas, M, Edina VF, McCutcheon SC. Phytoremediation: An ecological solution to organic chemical contamination. Ecol Eng. 2002;18:647-658. DOI: 10.1016/s0925-8574(02)00026-5.

[40] Mallavarapu M, Balasubramanian R, Kadiyala V, Nambrattil S, Ravi N. Bioremediation approaches for organic pollutants: A critical perspective. Environ Int. 2011;37(8):1362-1375. DOI: 10.1016/j.envint.2011.06.003.

[41] Scott C, Pandey G, Hartley CJ, Jackson CJ, Cheesman MJ, Taylor MC, et al. The enzymatic basis for pesticide bioremediation. Indian J Microbiol. 2008;48:65-79. DOI: 10.1007/s12088-008-0007-4.

[42] Arora PK, Kumar M, Chauhan A, Raghava GP, Jain RK. OxDBase: a database of oxygenases involved in biodegradation. BMC Res Notes. 2009;2:67. DOI: 10.1186/1756-0500-2-67.

[43] Arora PK, Srivastava A, Singh VP. Application of monooxygenases in dehalogenation, desulphurization, denitrification and hydroxylation of aromatic compounds. J Bioremed Biodegrad. 2010;1:1-8. DOI: 10.4172/2155-6199.1000112.

[44] Sing H, Löffler FE, Fathepure BZ. Aerobic biodegradation of vinyl chloride by a highly enriched mixed culture. Biodegradation. 2004;15(3):197-204. DOI: 10.1023/B:BIOD.0000026539.55941.73.

[45] Gossett JM. Sustained aerobic oxidation of vinyl chloride at low oxygen concentrations. Environ Sci Technol. 2010;44(4):1405-1411. DOI: 10.1021/es9033974.

[46] Jones JP, O'Hare EJ, Wong LL. Oxidation of polychlorinated benzenes by genetically engineered CYP101 (cytochrome P450cam). Eur J Biochem. 2001;268(5):1460-1467. DOI: 10.1046/j.1432-1327.2001.02018.x.

[47] Riffaldi R, Levi-Minzi R, Cardelli R, Palumbo S, Saviozzi A. Soil biological activities in monitoring the bioremediation of diesel oil-contaminated soil. Water Air Soil Pollut. 2006;170(1-4):3-15. DOI: 10.1007/s11270-006-6328-1.

[48] Chandra R, Chowdhary P. Properties of bacterial laccases and their application in bioremediation of industrial wastes. Environ Sci.: Processes Impacts. 2015;17:326-342. DOI: 10.1039/C4EM00627E.

[49] Kim JS, Park JW, Lee SE, Kim JE. Formation of bound residues of 8-hydroxybentazon by oxidoreductive catalysts in soil. J Agric Food Chem. 2002;50(12):3507-3511. DOI: 10.1021/jf011504z.

[50] Sharma D, Sharma B, Shukla AK. Biotechnological approach of microbial lipase: a review. Biotechnology. 2011;10: 23-40. DOI: 10.3923/biotech.2011.23.40. 
[51] Marchut-Mikolajczyk O, Kwapisz E, Wieczorek D, Antczak T. Biodegradation of diesel oil hydrocarbons enhanced with Mucor circinelloides enzyme preparation. Int Biodeter Biodegr. 2015;104:142-148. DOI: 10.1016/j.ibiod.2015.05.008.

[52] Rao MA, Scelza R, Scotti R, Gianfreda L. Role of enzymes in the remediation of polluted environments. J Soil Sci Plant Nutr. 2010;10(3):333-353. DOI: 10.4067/S0718-951620100 00100008.

[53] Margesin R, Labbé D, Schinner F, Greer CW, Whyte LG. Characterization of hydrocarbon-degrading microbial populations in contaminated and pristine alpine soils. Appl Environ Microbiol. 2003;69(6):3085-3092. DOI: 10.1128/AEM.69.6.3085-3092.2003.

[54] Ashby MN, Rine J, Mongodin EF, Nelson KE, Dimster-Denk D. Serial analysis of rRNA genes and the unexpected dominance of rare members of microbial communities. Appl Environ Microbiol. 2007;73(14):4532-4542. DOI: 10.1128/AEM.02956-06.

[55] Saavedra JM, Acevedo F, González M, Seeger M. Mineralization of PCBs by the genetically modified strain Cupriavidus necator JMS34 and its application for bioremediation of PCBs in soil. Appl Microbiol Biotechnol. 2010;87:1543-1554. DOI 10.1007/s00253-010-2575-6.

[56] Zhang R, Xu X, Chen W, Huang Q. Genetically engineered Pseudomonas putida X3 strain and its potential ability to bioremediate soil microcosms contaminated with methyl parathion and cadmium. Appl Microbiol Biotechnol. 2015. DOI 10.1007/s00253-015-7099-7.

[57] van der Lelie D, Lesaulnier C, McCorkle S, Geets J, Taghavi S, Dunn J. Use of single-point genome signature tags as a universal tagging method for microbial genome surveys. Appl Environ Microbiol. 2006;72(3):2092-2101. DOI: 10.1128/AEM.72.3.2092-2101.2006.

[58] Mello-Farias PC, Chaves ALS. Biochemical and molecular aspects of toxic metals phytoremediation using transgenic plants. In: Transgenic Approach in Plant Biochemistry and Physiology. Tiznado-Hernandez ME, Troncoso-Rojas R, Rivera-Dominguez MA, editors. Research Signpost, Kerala, India 2008; 253-266.

[59] Sriprang R, Murooka Y. Accumulation and detoxification of metals by plants and microbes. In: Environmental Bioremediation Technologies. Singh SN, Tripathi RD, editors. Berlin Heidelberg: Springer; 2007:77-100. http://link.springer.com/book/10.1007\%2F978-3-540-34793-4.

[60] Gupta DK, Huang HG, Corpas FJ. Lead tolerance in plants: strategies for phytoremediation. Environ Sci Pollut Res Int. 2013;20(4):2150-2161. DOI: 10.1007/s11356-013-1485-4.

[61] Vallee BL, Auld DS. Zinc coordination, function and structure of zinc enzymes and other proteins. Biochemistry. 1990;29(24):5647-5659. DOI: 10.1021/bi00476a001.

[62] Mejárea M, Bülow L. Metal-binding proteins and peptides in bioremediation and phytoremediation of heavy metals. Trends Biotechnol. 2001;19(2):67-73. DOI: 10.1016/S0167-7799(00)01534-1.

[63] Cai Y, Ma QL. Metal tolerance, accumulation, and detoxicification in plants with emphasis on arsenic in terrestrial plants. In: Biogeochemistry of environmentally important trace elements. Cai Y, Braids OC. editors. Washington, DC: American Chemical Society; 2003;8:95-114. DOI: 10.1021/bk-2003-0835.ch008.

[64] Yang X, Jin XF, Feng Y, Islam E. Molecular mechanisms and genetic bases of heavy metal tolerance/hyperaccumulation in plants. J Integr Plant Biol. 2005;47(9):1025-1035. DOI: 10.1111/j.1744-7909.2005.00144.x.

[65] Hossain MA, Piyatida P, da Silva TJA, Fujita M. Molecular mechanism of heavy metal toxicity and tolerance in plants: central role of glutathione in detoxification of reactive oxygen species and methylglyoxal and in heavy metal chelation. J Botany. 2012:1-40. DOI: 10.1155/2012/ 872875 .

[66] Zenk MH. Heavy metal detoxification in higher plants - a review. Gene. 1996;179(1):21-30. DOI: 10.1016/S0378-1119(96)00422-2.

[67] Xiang C, Oliver DJ. Glutathione metabolic genes co-ordinately respond to heavy metals and jasmonic acid in Arabidopsis. Plant Cell. 1998;10:1539-1550. http://www.ncbi.nlm.nih.gov/pmc/articles/PMC144077/ pdf/101539.pdf.

[68] Cherian GM, Chan HM. Biological functions of metallothioneins - a review. In: Metallothionein III: Biological Roles and Medical Implications. Suzuki KT, Kimura M, Imura N, editors. Boston: Birkhauser Verlag; 1993:87-109.

[69] Hassinen VH, Tervahauta AI, Schat H, Karenlampi SO. Plant metallothioneins - metal chelators with ROS scavenging activity. Plant Biol. 2011;13(2):225-232. DOI: 10.1111/j.1438-8677.2010.00398.x.

[70] Castiglione S, Franchin C, Fossati T, Lingua G, Torrigiani P, Biondi S. High zinc concentrations reduce rooting capacity and alter metallothionein gene expression in white poplar (Populus alba L. cv. Villafranca). Chemosphere. 2007;67(6):1117-1126. DOI: 10.1016/j.chemosphere.2006.11.039.

[71] Wood TK. Molecular approaches in bioremediation. Curr Opin Biotechnol. 2008;19(6):572-578. DOI: 10.1016/j.copbio.2008.10.003.

[72] Heaton ACP, Rugh CL, Wang NJ, Meagher RB. Physiological responses of transgenic merA-tobacco (Nicotiana tabacum) to foliar and root mercury exposure. Water Air Soil Pollut. 2005;161:137-155. DOI: 10.1007/s11270-005-7111-4. 
[73] Bode M, Stobe P, Thiede B, Schuphan I, Schmidt B. Biotransformation of atrazine in transgenic tobacco cell culture expressing human P450. Pest Manage Sci. 2004;60:49-58. DOI: 10.1002/ps.770.

[74] Neufeld JD, Mohn WW, de Lorenzo V. Composition of microbial communities in hexachlorocyclohexane $(\mathrm{HCH})$ contaminated soils from Spain revealed with a habitat-specific microarray. Environ Microbiol. 2006;8(1):126-140. DOI: 10.1111/j.1462-2920.2005.00875.x.

[75] Fan G, Cang L, Qin W, Zhou C. Gomes HI, Zhou D. Surfactants-enhanced electrokinetic transport of xanthan gum stabilized nano $\mathrm{Pd} / \mathrm{Fe}$ for the remediation of PCBs contaminated soils. Sep Purif Technol. 2013;114:64-72. DOI: 10.1016/j.seppur.2013.04.030.

[76] Husseiny MI, El-Aziz MA, Badr Y, Mahmoud MA. Biosynthesis of gold nanoparticles using Pseudomonas aeruginosa. Spectrochim Acta Mol Biomol Spectrosc. 2007;67:1003-1006. DOI: 10.1016/j.saa.2006.09.028.

[77] Shin KH, Cha DK. Microbial reduction of nitrate in the presence of nanoscale zero-valent iron. Chemosphere. 2008;72(2):257-262. DOI: 10.1016/j.chemosphere.2008.01.043.

[78] Shan GB, Xing JM, Zhang HY, Liu HZ. Biodesulfurization of dibenzothiophene by microbial cells coated with magnetite nanoparticles. Appl Environ Microbiol. 2005;71:4497-4502. DOI: 10.1128/AEM.71.8.44974502.2005 .

[79] Hulkoti NI, Taranath TC. Biosynthesis of nanoparticles using microbes; a review. Colloid Surf B: 2014;121:474-483. DOI: 10.1016/j.colsurfb.2014.05.027.

[80] Sharma NC, Sahi SV, Nath S, Parsons JG, Gardea-Torresdey JL, Pal T. Synthesis of plant-mediated gold nanoparticles and catalytic role of biomatrix-embedded nanomaterials. Environ Sci Technol. 2007;41(14):5137-5142. DOI: 10.1021/es062929a.

[81] Beattie IR, Haverkamp RG. Silver and gold nanoparticles in plants: sites for the reduction to metal. Metallomics. 2011;3:628-632. DOI: 10.1039/c1mt00044f.

[82] Zhang YX, Zheng J, Gao G, Kong YF, Zhi X, Wang K, et al. Biosynthesis of gold nanoparticles using chloroplasts. Int J Nanomed. 2011;6:2899-2906. DOI: 10.2147/IJN.S24785.

[83] Liu R, Zhao D. Reducing leachability and bioaccessibility of lead in soils using a new class of stabilized iron phosphate nanoparticles. Water Res. 2007;41(12):2491-2502. DOI: 10.1016/j.watres.2007.03.026.

[84] Cameotra SS, Dhanjal S. Environmental nanotechnology: nanoparticles for bioremediation of toxic pollutants. Bioremed Technol. 2010;348-374. DOI: 10.1007/978-90-481-3678-0_13.

[85] Baek KH, Yoon BD, Cho DH, Kim BH, Oh HM, Kim HS. Monitoring bacterial population dynamics using real-time PCR during the bioremediation of crude-oil contaminated soil. J Microbiol Biotechnol. 2009;19:339-345 . DOI: 10.4014/jmb.0807.423.

[86] Jerez CA. Biomining microorganisms: molecular aspects and applications in biotechnology and bioremediation. In: Advances in Applied Bioremediation. Berlin: Springer; 2009:239-256. DOI: 10.1007/978-3-540-89621-0_13.

[87] Paliwal V, Chande S, Purohit H. Integrated perspective for effective bioremediation. Appl Biochem Biotechnol. 2012:166:903-924. DOI 10.1007/s12010-011-9479-5.

[88] Peijnenburg WJGM, Zablotskaja M, Vijver MG. Monitoring metals in terrestrial environments within a bioavailability framework and focus on soil extraction. Ecotoxicol Environ Safety. 2007;67(2):163-179. DOI: 10.1016/j.ecoenv.2007.02.008.

[89] Quevauviller P, editor. Methodologies for Soil and Sediment Fractionation Studies. Brussels, Belgium: Royal Society of Chemistry; 2002. DOI: 10.1039/9781847551412.

[90] Seleznev AA, Yarmoshenko IV. Study of urban puddle sediments for understanding heavy metal pollution in an urban environment. Environ Technol Innov. 2014;1-2:1-7. DOI: 10.1016/j.eti.2014.08.001.

[91] Mishra V, Lal R, Srinivasan S. Enzymes and operons mediating xenobiotic degradation in bacteria. Crit Rev Microbiol. 2001;27:133-166. DOI: 10.1080/20014091096729.

[92] Sar P, Kazy SK, Singh SP. Intracellular nickel accumulation by Pseudomonas aeruginosa and its chemical nature. Lett Appl Microbiol. 2001;32(4):257-261. DOI: 10.1046/j.1472-765X.2001.00878.x.

[93] Gupta VVSR, Dick RP, Coleman DC. Functional microbial ecology: Molecular approaches to microbial ecology and microbial habitats. Soil Biol Biochem. 2008;40:1269-1271. DOI: 10.1016/S0038-0717(08)00044-8.

[94] Naranjo L, Urbinaa H, De Sistoa A, Leona V. Isolation of autochthonous non-white rot fungi with potential for enzymatic upgrading of Venezuelan extra-heavy crude oil. Biocatal Biotransform. 2007;25:341-349. DOI: $10.1080 / 10242420701379908$.

[95] Nielsen MN, Winding A. Microorganisms as indicators of soil heath. NERI Technical Report No. 388, Ministry of the Environment. National Environmental Research Institute. Denmark 2002. http://www.dmu.dk/1_viden/2_publikationer/3_fagrapporter/rapporter/FR388.pdf.

[96] Steliga T, Jakubowicz P, Kapusta P. Optimisation research of petroleum hydrocarbons biodegradation in weathered drilling wastes from waste pits. Waste Manage Res. 2010;28(12):1065-1075. DOI: 10.1177/0734242X09351906. 
[97] Juvonen R, Martikainen E, Schultz E, Joutti A, Ahtiainen J, Lehtokaris M. A battery of toxicity tests as indicators of decont amination in composting oily waste. Ecotoxicol Environ Saf. 2000;47:156-166.

[98] Steliga T, Jakubowicz P, Kapusta P. Changes in toxicity during in situ bioremediation of weathered drill wastes contaminated with petroleum hydrocarbons. Biores Technol. 2012;125:1-10. DOI: 10.1016/j.biortech.2012.08.092.

[99] Xu L, Teng Y, Li ZG, Norton JM, Luo YM. Enhanced removal of polychlorinated biphenyls from alfalfa rhizosphere soil in a field study: the impact of a rhizobial inoculums. Sci Total Environ. 2010;408:1007-1013. DOI: 10.1016/j.scitotenv.2009.11.031.

[100] Teng Y, Luo Y, Sun X, Tu C, Xu L, Liu W, et al. Influence of arbuscular mycorrhiza and rhizobium on phytoremediation by alfalfa of an agricultural soil contaminated with weathered PCBs: a field study. Int J Phytoremed. 2010;12:516-533. DOI: 10.1080/15226510903353120. 